\title{
CORRELATION OF GLYCOSYLATED HEMOGLOBIN LEVELS WITH AUDITORY AND VISUAL REACTION TIME IN DIABETICS
}

\author{
${ }^{1}$ Shweta Patil https://orcid.org/0000-0002-8997-5036 \\ ${ }^{2}$ Sangita Phatale https://orcid.org/0000-0002-0490-4379 \\ ${ }^{3}$ Basavaraj Malipatil https://orcid.org/0000-0001-7288-4333 \\ ${ }^{l}$ S. Nijlingappa Medical College \& Hanagal Shri Kumareshwar Hospital, Bagalkot, Karnataka, \\ India ${ }^{2}$ Mahatma Gandhi Mission Medical College, Aurangabad, Maharastra, India \\ ${ }^{3}$ Mahadevappa Rampure Medical College, Gulbarga, Karnataka, India \\ patilshw@gmail.com
}

Relevance. Diabetes mellitus is a group of metabolic disorders wherein hyperglycemia occurs either due to lack of insulin secretion and/or reduced insulin sensitivity of the tissues. One of the commonest complications of diabetes is neuropathy and its severity will depend on how long and how high the hyperglycemia has been prevalent. Chronic hyperglycemia in diabetes affects the peripheral nerves and slows psychomotor responses in persons who do not have proper glycemic control. This decreased psychomotor response because of improper glycemic control affects the reaction time in diabetics.

Objective: to assess and compare the auditory and visual reaction time in group-1 and group-2 diabetics and to correlate it with glycosylated hemoglobin (HbA1c) levels in both the groups.

Methods. The study was conducted on 60 subjects aged between $40-50$ years after obtaining the permission of the ethical committee of our institution. The group consisted of 60 well controlled diabetic patients (HbAlc $<7 \%$ ) with history of diabetes for $1-10$ years attending the medical OPD of Basaveshwar teaching and general hospital, Gulbarga. Diabetics with HbA1c 5-6\% were grouped as group-1 and those with HbA1c 6-7\% as group 2. The visual reaction time for green and red light and auditory reaction time for tone and click sound was measured by using reaction time apparatus 2x4, Anand agencies Pune. HbA1c was done by micro-column method.

Results. The visual and auditory reaction time of diabetics with $\mathrm{HbAlc} 5-6 \%$ was faster as compared to the diabetics with $\mathrm{HbA1c}$ $6-7 \%$ with $\mathrm{P}<0.001$ and a statistically significant positive correlation was found between $\mathrm{HbA} 1 \mathrm{c}$ levels and the visual and auditory reaction time.

Conclusion. Poor glycemic control slows psychomotor responses and thus affects the visual and auditory reaction time.

Key words: Diabetes, Hyperglycemia, Glycemic control, Reaction time, HbA1c, Diabetic Neuropathy.

Relevance. Diabetes mellitus is prevalent worldwide. About 285 million people had diabetes, with type 2 contributing to $90 \%$ of the cases [1]. The incidence of diabetes is rising, and by 2030 , this number is estimated to almost double [2]. In India more than 62 million individuals are currently diagnosed with the diabetes [3,4]. With this rapidly increasing rate diabetes could be considered to be a potential epidemic in India. The etiology of diabetes is multifactorial. It may be due to and genetic factors along with change of lifestyle, easy access junk foods, sedentary life, stress and steady urban migration. Even with this increasing incidence of diabetes in India, there are only a few studies conducted on the prevalence of diabetes and its complications. One of the major causes of mortality and morbidity in our country is diabetes mellitus, which is due to high blood glucose levels. About four million deaths in the 20-79 age group were probably caused due to diabetes in 2010, which was about $6.8 \%$ of global all-cause mortality in this age group.

Diabetes mellitus is a metabolic disease characterized by hyperglycemia which may be due to insufficient insulin secretion and/or reduced insulin sensitivity to the tissue. It is associated with abnormal glucose, lipid and protein metabolism. The chronic hyperglycemia has a higher risk of developing neuropathy, microangiopathy, atherosclerosis and impaired wound healing. Diabetes mellitus can affect multiple organs in the body, some of which may be fatal. A less addressed and not so well recognised complication of diabetes is cognitive dysfunction. Cognitive dysfunction found in diabetic patients were related to their disease. The first noticed case of cognitive dysfunction in diabetes mellitus patient was in 1922, where diabetic patients 'who were free from acidosis but usually not sugar free', had impaired memory and attention when cognitive test was done.

Diabetes mellitus causes both microvascular and macrovascular complications. It has been shown in studies that microvascular complications are mainly because of hyperglycemia, whereas insulin resistance is the major determinant in macrovascular disease [5]. Diabetic neuropathy is an important cause of sudden deaths in diabetics and both the degree of glycemic control and duration of diabetes are responsible for it, though the onset of this complication is more dependent on the duration of diabetes.

Diabetic neuropathy (DN) is defined as, patient with diabetes mellitus (DM) having signs and symptoms of peripheral nerve dysfunction wherein other causes of 
peripheral nerve dysfunction have been excluded. The incidence of DN in India is not well known but a study from South India showed that $19.1 \%$ type II diabetic patients had peripheral neuropathy [6]. One of the commonest causes of peripheral neuropathy is DN and it requires more frequent hospitalisation than any other complications of diabetes. It is also one of the commonest causes of non-traumatic amputation. All types of diabetic patients-insulin dependent diabetes mellitus (IDDM), noninsulin dependent diabetes mellitus (NIDDM), and secondary diabetic patients-can develop neuropathy. The prevalence of diabetic neuropathy varies in various studies due to inconsistency in the definition of neuropathy. The best data regarding prevalence of neuropathy came from the extensive study of nearly 4400 clinic patients undertaken by Pirart. According to his study the prevalence rate of $\mathrm{DN}$ ranges from $7 \%$ to $50 \%$ depending on the duration of diabetes, with $7 \%$ within one year of diagnosis to $50 \%$ for those with more than 25 years of diabetes. Males were more affected than females. The risk for the complication of neuropathy increases with increasing duration and severity of hyperglycemia.

The development of diabetic neuropathy is probably due to vascular lesions and it was first considered in 1893 and was supported by the pathologic studies of Woltman and Wolder in 1929. They concluded that "atherosclerosis of nutrient vessel of the nerve plays a leading part in the production of diabetic neuritis".

Pathogenesis of diabetic neuropathy is multifactorial. Pathologic changes inherent to neurons caused by hyperglycemia [7] and ischemic damage to the neurons caused by decreased neurovascular blood flow [8] both factors are responsible. Because of these vascular elements, diabetic neuropathy is considered to be a microvascular complication.

Chronic hyperglycaemia in diabetes affects peripheral nerves in the somato-sensory system. It also slows psychomotor responses in those individuals without proper glycemic control, which may affect reaction time.

Reaction time (RT) is the elapsed time between the presentation of a sensory stimulus and the subsequent behavioral response. Different types of stimuli can be tried to elicit a particular response such as light, sound, etc. The measure of reaction time has been used to evaluate the processing speed [9] of Central Nervous System, the co-ordination between the sensory and motor systems [10] and performance of an individual.

Glycosylated hemoglobin is widely accepted and the most reliable test for assessing glycemic control. Persistent hyperglycemia causes non-enzymatic glycosylation of polypeptides and proteins, including hemoglobin. Of all the Glycosylated form of hemoglobin, $\mathrm{HbAlc}$ is the most stable, more than 80 per cent of the Glycosylated form is HbA1c. Glycosylated hemoglobin is an index of long-term blood glucose concentrations and it also helps to assess the risk for the development of complications in patients with diabetes mellitus [11].
Lowering of $\mathrm{HbA} 1 \mathrm{c}$ reduces the risk of neuropathic, microvascular and possibly macrovascular complications of diabetes [12]. So strict glycemic control is important in delaying the onset and progression of microvascular complications of diabetes including neuropathy. Hence, it is recommended that HbAlc testing be used as a preventive measure to reduce morbidity and mortality due to complications of diabetes in the community.

Diabetic neuropathy is the most common complication in diabetes, chronic hyperglycemia being the important cause for it. Studies with comparison between diabetic patients and control groups have been done, our study involves only the controlled diabetic patients in order to highlight the importance of glycemic control in reducing the morbidity and mortality in diabetics due to neuropathy. The current study is done by measuring the auditory and visual reaction time, and $\mathrm{HbAlc}$. The auditory and visual reaction time is correlated with HbA1c levels.

Objective: to assess and compare the auditory and visual reaction time in group-1 and group-2 diabetics and to correlate it with $\mathrm{HbA} 1 \mathrm{c}$ levels in both the groups.

\section{METHODS}

After obtaining the permission from the ethical committee of our institution (M R medical college, Gulbarga) the study was conducted on 60 subjects aged between 40-50 years. The group consisted of 60 well controlled diabetic patients $(\mathrm{HbA} 1 \mathrm{c}<7 \%$ ) with history of diabetes for 1-10 years attending the medical OPD of Basaveshwar teaching and general hospital, Gulbarga. Diabetics with $\mathrm{HbA} 1 \mathrm{c} 5-6 \%$ were grouped as group-1 and those with $\mathrm{HbA} 1 \mathrm{c} 6-7 \%$ as group 2. Diabetics with auditory or visual disturbance, Alcoholics, hypertensives, smokers, Clinical evidence of peripheral neuropathy, Muscle weakness, myopathy, Mental or psychological disorders, Neurovascular complications, any pathology or injury to the upper limb and Clinical evidence of any other illnesses which effect the reaction time were excluded from the study.

HbA1c is done by micro column method which contains a pre-weighted amount of resin equilibrated with phosphate buffer $72 \mathrm{mmol} / \mathrm{L}$, pH6.5. Sodium azide $0.95 \mathrm{~g} / \mathrm{L}$. After preparing the hemolysate, where the labile fraction is eliminated. HbAlc is specifically eluted after washing away the $\mathrm{HbAl} \mathrm{a}+\mathrm{b}$ fraction and is quantified by direct photometric reading at $415 \mathrm{~nm}$.

The Auditory and visual reaction time was measured using reaction time apparatus. This apparatus is a portable research reaction timer with 2 response choices. It has an inbuilt chronoscope-4 digit chronoscope with least count of 1/1000 seconds and works on 230 volts AC. The apparatus has two sides, one 'S's (Subject) and the other 'E's (Examiner). There are 4 keys, and 4 selector switches on 'E"'s side for selecting 'S's left or right key. When the key marked green light is pressed on the ' $E$ 's side ' $S$ ' 
will see the same on his side. Similarly, for the red light, buzzer and click. The push button on E's side rings the bell. This is a signal for $\mathrm{S}$ to press the right or left key as selected by E' with the selector switch. Then E presses any of the keys giving the required stimulus. The stimulus key is double key. It gives the stimulus and also starts the chronoscope. As soon as the stimulus is received $\mathrm{S}$ lifts his finger from the right or left key. This stops the chronoscope and thus reaction time to any of the stimuli is obtained. All the subjects are thoroughly acquainted with apparatus and 3 readings were taken after practice trials for 4 stimuli i-e; Red and Green colour for visual reaction time, Tone and Click for Auditory reaction time. Reaction time was recorded using the dominant hand.

Statistical method used: Student $t$ test and Pearson's correlation co-efficient were used wherever ap- propriate to analyse the data. P Value $<0.001-$ Highly Significant, P Value $<0.01$ - Moderately significant. $\mathrm{P}$ Value $<0.05$ - Significant, P Value $>0.05-$ Not Significant.

\section{RESULTS AND DISCUSSION}

Table- 1 and Figure-1 depict comparison of VRT and ART with HbAlc levels in diabetics. The table shows that the VRT for green and red light stimuli and ART for tone and click sound stimuli is prolonged in group-2 diabetics than in group- 1 diabetics with $\mathrm{P}<0.001$ which is statistically extremely significant.

Table-2 shows significant positive correlation with $\mathrm{P}<0.001$ between HbA1c 5-6\% and visual green light and a significant positive correlation with auditory click sound reaction times $\mathrm{P}$ value being $<0.05$.

Table 1

Comparison of Visual and Auditory Reaction Time in Group-1 and Group-2 Diabetics

\begin{tabular}{|c|c|c|c|c|c|}
\hline \multicolumn{2}{|c|}{ Reaction Time, msec } & Group-1 & Group-2 & P-Value \\
\hline \multirow{2}{*}{ Visual } & Green & $0.199 \pm 0.014$ & $0.2445 \pm 0.021$ & $\mathrm{t}=11.37$ \\
\cline { 2 - 6 } & Red & $0.214 \pm 0.009$ & $0.2442 \pm 0.023$ & $\mathrm{t}=6.04$ \\
\hline \multirow{2}{*}{ Auditory } & Tone & $0.174 \pm 0.0129$ & $0.203 \pm 0.0144$ & $\mathrm{t}=7.38$ \\
\cline { 2 - 6 } & Click & $0.170 \pm 0.0073$ & $0.1992 \pm 0.0166$ & $\mathrm{t}=8.78$ \\
\hline
\end{tabular}

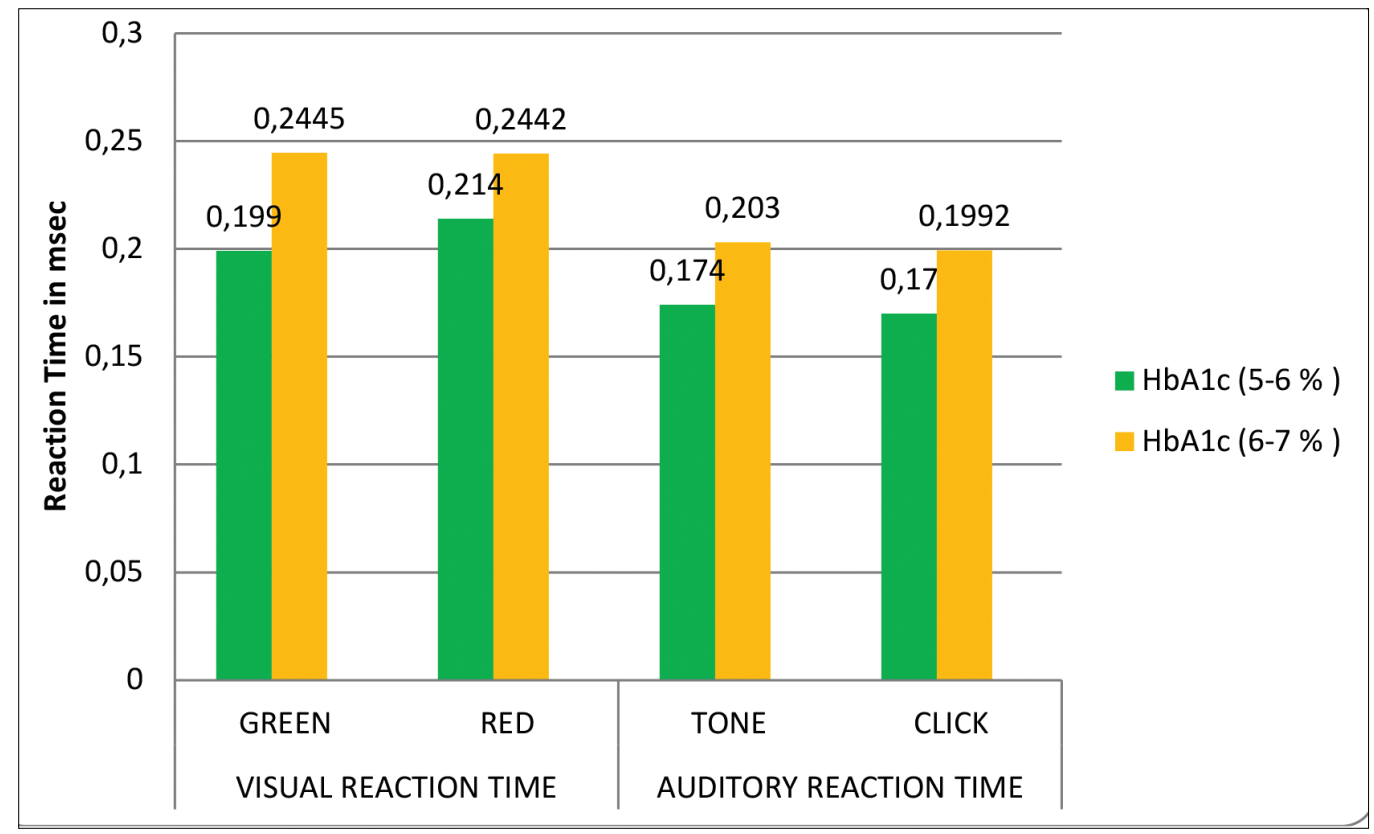

Fig. 1. Comparison of Visual and Auditory Reaction Time in Group-1 and Group-2 Diabetics

Correlation between HbA1c Level and Visual and Auditory Reaction Time in group-1 Diabetics

\begin{tabular}{|c|c|c|c|}
\hline \multicolumn{2}{|c|}{ Reaction time, msec } & Correlation coefficient, (R) & P-Value \\
\hline \multirow{2}{*}{ Visual } & Green & 0.662 & $\mathrm{P}<0.001$ \\
\cline { 2 - 4 } & Red & 0.295 & $\mathrm{P}>0.05$ \\
\hline \multirow{2}{*}{ Auditory } & Tone & 0.356 & $\mathrm{P}>0.05$ \\
\cline { 2 - 4 } & Click & 0.428 & $\mathrm{P}<0.05$ \\
\hline
\end{tabular}


Correlation between HbA1c Level and Visual and Auditory reaction time in group-2 diabetics

\begin{tabular}{|c|c|c|c|}
\hline \multicolumn{2}{|c|}{ Reaction Time, msec } & Correlation coefficient, (r) & P-Value \\
\hline \multirow{2}{*}{ Visual } & Green & 0.769 & $\mathrm{P}<0.01$ \\
\cline { 2 - 4 } & Red & 0.502 & $\mathrm{P}<0.01$ \\
\hline \multirow{2}{*}{ Auditory } & Tone & 0.649 & $\mathrm{P}<0.01$ \\
\cline { 2 - 4 } & Click & 0.710 & $\mathrm{P}<0.01$ \\
\hline
\end{tabular}

Table-3 shows highly significant correlation between $\mathrm{HbA1c} 6-7 \%$ and visual green and red light and auditory tone and click sound reaction times.

In our study, we found that diabetics with $\mathrm{HbAlc}$ 5-6\% performed better than diabetics with $\mathrm{HbA} 1 \mathrm{c}$ 6-7\% with a significant positive correlation between $\mathrm{HbA} 1 \mathrm{c}$ levels and visual and auditory reaction time. Improper glycemic control reduces psychomotor efficiency, motor speed and attention. The enzyme aldose reductase is activated by the intracellular hyperglycemia which in turn increases the formation of sorbitol. Thus, sorbitol gets accumulated. It is neurotoxic and reduces the Na-K ATPase activity of the cell. As a result of uncontrolled hyperglycemia, the sodium-dependent myo-inositol uptake is competitively inhibited. It is hypothesized that this decreased uptake leads to the decreased concentration of myo-inositol in peripheral nerves and also decrease in the sodium potassium ATPase activity which leads to decrease in nerve conduction.

Longstanding hyperglycemia causes an increased flux of the polyol pathway, enhanced advanced glycation end-products formation, excessive release of cytokines, activation of protein kinase $\mathrm{C}$ and exaggerated oxidative stress all of which leads to peripheral nerve injury. Extremely long axons which originate in the small neuronal body are more likely to be affected on their most distal side because of malnutritional axonal support or environmental insults. Deficient vascular supply with impaired autoregulation is the most likely cause of hypoxic damage in the nerve. Such effects caused by long-term hyperglycemia are critical for peripheral nerve damage, resulting in distal-predominant nerve fiber degeneration. The axonal degeneration of both the myelinated and unmyelinated fibers, axonal shrinkage, thickening of the basement membrane and microthrombi are responsible for delayed motor nerve conduction and hence, the increased reaction time.

The DCCT has documented that there is a direct relation between blood glucose concentrations as measured by $\mathrm{HbA} 1 \mathrm{c}$ and the risk of complications. The risk of microvascular complications varies continuously with $\mathrm{HbA}$ 1c concentration below which risk is eliminated. Analogous correlations between $\mathrm{HbA} 1 \mathrm{c}$ and complications were observed in patients with diabetes type 2 mellitus in the UKPDS trial. Each 1\% reduction in HbA1c (e.g. from $8 \%$ to $7 \%$ ) was associated with risk reduction of $37 \%$ for micro vascular complications. An increase of $1 \%$ in $\mathrm{HbA} 1 \mathrm{c}$ was associated with a $28 \%$ increase in the risk of death [13]. Based on the DCCT and UKPDS the ADA recommends that a primary treatment goal in adults with diabetes should be near-normal glycemia with $\mathrm{HbA} 1 \mathrm{c}$ less than $7 \%$.

Graf RJ et al. found baseline HbAlc levels correlated with the incidence of peripheral neuropathy. But study by Susenko et al. found no correlation between $\mathrm{HbA} 1 \mathrm{c}$ levels and peripheral neuropathy. In a study by Padilla-Medina JA et al, the diabetic patients simple reaction times (SRT) were an average $24 \%$ longer than the reaction time in non-diabetic group and a significant average difference of $41 \%$ was obtained in choice reaction time studied through performance indexes (d'). A positive correlation of 0.6594 between the duration of diabetes and SRT of diabetic patients was obtained [14, 15]. On the contrary, Dey J et al, found no correlation between the duration of diabetes and cognitive function in those with NIDDM less than 18 years. S Venkataraman, V S Ganesan and others found that a reduction in the glycemic levels from the hyperglycemic range resulted in a significant improvement in VRT, one of the indices of cognitive skills routinely performed in diabetic subjects.

The study conducted by Christoper M Ryan and Theresa M Williams to examine learning and memory processes in a group of 82 younger adults with a longstanding history of childhood $\backslash$ onset IDDM, showed that they performed worse on measures of psychomotor efficiency, with degree of chronic hyperglycemia being the best predictor of psychomotor slowing.

Clarrisa Smith Holmes et al, found that the rapid motor responses following a visual stimulus was delayed in diabetic subjects at extremes of glucose levels compared to euglycemic state. Paradoxically, Flender and Lifshitz observed improved fine motor coordination at elevated blood glucose levels. Franklin GM, Kahan LB, Baxter J, Marshall JA, Hamman RE found neuropathy to be significantly associated with duration of diabetes, glycemic control, age, height and male gender.

Limitations. The major drawback of our study is that we have examined only auditory and visual reaction time for demonstrating correlation between $\mathrm{HbAlc}$ levels and neuropathy. Since auditory and visual reaction time can be affected by so many other factors it is practically impossible to exclude all of them in these patients. Hence, additional pathological and functional tests have to be done in order to substantiate the mechanisms responsible 
for the differences in auditory and visual reaction time that we have seen in these two groups.

\section{CONCLUSION}

We found a positive correlation between $\mathrm{HbAlc}$ levels and visual and auditory reaction times in our study. This shows that poor glycemic control slows psychomotor responses. We conclude our study with the observation that, glycemic control (HbAlc levels) affects the visual and auditory reaction time in diabetics.

\section{REFERENCES}

1. Wild S, Roglic G, Green A, Sicree R, King H. Global prevalence of diabetes: Estimates for the year 2000 and projections for 2030. Diabetes Care. 2004; 27 (5): 1047-53. DOI: 10.2337/diacare.27.5.1047

View at: Publisher Site: https:/care.diabetesjournals. org/content/27/5/1047

2. PubMed: https://pubmed.ncbi.nlm.nih.gov/15111519/ The Diabetes Atlas. Ninth Edition. Brussels: International Diabetes Federation, 2019.

View at: Publisher Site: https://idf.org/e-library/epidemiology-research/diabetes-atlas.html

URL: https://www.diabetesatlas.org/upload/resources/ material/20200302_133351_IDFATLAS9e-final-web. pdf

3. Joshi SR, Parikh RM. India - diabetes capital of the world: now heading towards hypertension. J Assoc Physicians India. 2007;55:323-4.

View at: Publisher Site: https://www.japi.org/t2f45494/ india-diabetes-capital-of-the-world-now-heading-towards-hypertension

PubMed: https://pubmed.ncbi.nlm.nih.gov/17844690/

4. Kumar A, Goel MK, Jain RB, Khanna P, Chaudhary $\mathrm{V}$. India towards diabetes control: Key issues. Australas Med J. 2013;6(10):524-31. DOI: 10.4066/ AMJ.2013.1791

View at: PubMed: https://pubmed.ncbi.nlm.nih. gov/24223071/

PubMed Central: https:/www.ncbi.nlm.nih.gov/pmc/ articles/PMC3821052/

5. Brownlee M. The pathobiology of diabetic complications. A unifying mechanism. Diabetes. 2005; 54(6):1615-25. DOI: 10.2337/diabetes.54.6.1615

View at: Publisher Site: https://diabetes.diabetesjournals.org/content/54/6/1615

PubMed: https://pubmed.ncbi.nlm.nih.gov/15919781/

7. Ashok S, Ramu M, Deepa R, Mohan V. Prevalence of neuropathy in type 2 diabetes patients attending diabetes center in South India. J Assoc Physicians India. 2002; 50: 546-50.

View at: PubMed: https://pubmed.ncbi.nlm.nih. gov/12164406/

8. Eichberg J. Protein kinase $\mathrm{C}$ changes in diabetes: is the concept relevant to neuropathy? Int rev neurobiol. 2002; 50:61-82. DOI: 10.1016/ s0074-7742(02)50073-8

View at: Publisher Site: https://www.sciencedirect.com/science/article/abs/pii/ S0074774202500738?via\%3Dihub

PubMed: https://pubmed.ncbi.nlm.nih.gov/12198821/

9. Sugimoto K, Murakawa Y, Sima AA. Diabetic neuropathy-A continuing enigma. Diabetes Metab Res Rev. 2000; 16(6):408-33. DOI: 10.1002/1520-7560(200011/12)16:6<408::aid-dmrr158>3.0.co;2-r.

View at: Publisher Site: https://onlinelibrary.wiley. com/doi/10.1002/1520-7560(200011/12)16:6\%3C40 8::AID-DMRR158\%3E3.0.CO;2-R

PubMed: https://pubmed.ncbi.nlm.nih.gov/11114101/

10. Jensen A. Clocking the mind: Mental chronometry and individual differences. Amsterdam: Elsevier, 2006. $286 \mathrm{p}$.

View at: Publisher Site: https://www.elsevier.com/ books/clocking-the-mind/jensen/978-0-08-044939-5 URL: https://lesacreduprintemps19.files.wordpress. com/2012/11/clocking-the-mind-mental-chronometry-and-individual-differences.pdf

11. Venkatesh D, Rmamachandra DL, Baboo NS, Rajan BK. Impact of psychological stress, gender and color on visual response latency. Indian J Physiol Pharmacol. 2002;46(3):333-7.

View at: PubMed: https://pubmed.ncbi.nlm.nih. gov/12613397/

12. Goldstein DE, Little RR, Lorenz RA, Malone JI, Nathan D, Charles M, Peterson CM, Sacks DB. Tests of glycemia in diabetes. Diabetes care. 2004; 27(7):176173. DOI: $10.2337 /$ diacare.27.7.1761

View at: Publisher Site: https://care.diabetesjournals. org/content/27/7/1761

PubMed: https://pubmed.ncbi.nlm.nih.gov/15220264/

13. American Diabetes Association. Standards of Medical Care in Diabetes - 2014. Diabetes Care. 2014; 37 (Suppl. 1): S14-S80. DOI: 10.2337/dc14-S014.

View at: Publisher Site: https://care.diabetesjournals. org/content/37/Supplement_1/S14

PubMed: https://pubmed.ncbi.nlm.nih.gov/24357209/

14. Khaw KT, Wareham N, Luben R, Bingham S, Oakes S, Welch A, Day N. Glycated hemoglobin, diabetes, and mortality in men in Norfolk cohort of European prospective investigation of cancer and nutrition (EPIC-NORFOLK). BMJ. 2001; 322(7277):15-8. DOI: 10.1136/bmj.322.7277.15

Publisher Site: https://www.bmj.com/research PubMed: https://pubmed.ncbi.nlm.nih.gov/11141143/ PubMed Central: https://www.ncbi.nlm.nih.gov/pmc/ articles/PMC26599/

15. Padilla-Medina JA, Prado-Olivarez J, Amador-Licona N, Cardona-Torres LM, Galicia-Resendiz D, Diaz-Carmona J. Study on simple reaction and choice times in patients with type I diabetes. Comput Biol 
Med. 2013 May 1; 43(4):368-76. DOI: 10.1016/j. compbiomed.2013.01.010

View at: Publisher Site: https://www.sciencedirect.com/science/article/abs/pii/ S0010482513000243?via\%3Dihub

PubMed: https://pubmed.ncbi.nlm.nih.gov/23402936/

16. Sanchez-Marin FJ, Padilla-Medina JA. Simple reaction times and performance in the detection of visual stimuli of patients with diabetes. Comput Biol Med. 2010 Jun; 40(6):591-6. DOI: 10.1016/j. compbiomed.2010.04.003

View at: Publisher Site: https://www.sciencedirect.com/science/article/abs/pii/ S0010482510000673?via\%3Dihub

PubMed: https://pubmed.ncbi.nlm.nih.gov/20451904/

\title{
ВЗАЄМОЗВ'ЯЗОК РІВНЯ ГЛІКОЗИЛЬОВАНОГО ГЕМОГЛОБІНУ І ЧАСУ СЛУХОВОЇ ТА ЗОРОВОЇ РЕАКЦІЙ ПРИ ДІАБЕТІ
}

\author{
${ }^{1}$ Швета Патіл, ${ }^{2}$ Сангіма Фаталє, ${ }^{3}$ Басавараджс Маліпатіл \\ ${ }^{1}$ Медичний коледж імені С. Ніджлінгпаппи та лікарня Ханагал Шрі Кумарешвар, Багалкот, \\ Карнатака, Індія \\ ${ }^{2}$ Медичний коледж місії Махатми Ганді, Аурангабад, Махарастра, Індія \\ ${ }^{3}$ Медичний коледж Махадеваппи Рампуре, Гулбарга, Карнатака, Індія \\ patilshw@gmail.com
}

Актуальність. Цукровий діабет є групою метаболічних порушень, при яких гіперглікемія виникає або через недостатній секреції інсуліну, або через зниження чутливості тканин до інсуліну. Одним з найбільш поширених ускладнень діабету є нейропатія, і ії тяжкість буде залежати від ступеня і тривалості гіперглікемії. Хронічна гіперглікемія при діабеті призводить до ураження периферичних нервів і уповільнює швидкість реакції у людей, у яких відсутній належний глікемічний контроль. Зниження психомоторной реакції через недостатність глікемічного контролю впливає на час реакції у діабетиків.

Ціль: оцінити і порівняти час слухової і зорової реакцій у хворих на діабет в групах 1 та 2, і провести кореляцію 3 рівнем глікозильованого гемоглобіну (HbA1c) в обох групах.

Методи. Дослідження проводилося за участю 60 осіб у віці від 40 до 50 років після отримання дозволу етичного комітету нашого інституту. Група складалася з 60 пацієнтів з добре контрольованим діабетом (HbA1c <7\%) в анамнезі від 1 до 10 років, які відвідували медичний центр OPD в Басаешвар, Гулбарга. Пацієнти з рівнем гемоглобіну НbА1c 5-6\% були згруповані в групу 1, а пацієнти з НbA1c 6-7\% - до групи 2. Час зорової реакції на зелений і червоний світло, і час слухової реакції на звук і клацання вимірювали за допомогою приладу визначення часу реакції 2x4, Anand agencies Pune. HbА1с визначали методом мікроколонки.

Результати. Час зорової та слухової реакцій у хворих на діабет групи 1 (НbA1c 5-6\%) було швидше $\mathrm{P}<0,001$ у порівнянні 3 хворими групи 2 (НbAlc 6-7\%). Також була виявлена статистично значуща позитивна кореляція між рівнем НbA1c i часом зорової та слухової реакцій.

Висновки. Поганий глікемічний контроль уповільнює швидкість реакції і таким чином впливає на час зорової та слухової реакцій.

Ключові слова: діабет, гіперглікемія, глікемічний контроль, час реакції, НbA1c, діабетична нейропатія.

\section{ВЗАИМОСВЯЗЬ УРОВНЯ ГЛИКОЗИЛИРОВАННОГО ГЕМОГЛОБИНА И ВРЕМЕНИ СЛУХОВОЙ И ЗРИТЕЛЬНОЙ РЕАКЦИЙ ПРИ ДИАБЕТЕ}

\author{
${ }^{1}$ Швета Патил, ${ }^{2}$ Сангита Фатале, ${ }^{3}$ Басавараджс Малипатил \\ ${ }^{1}$ Медицинский колледж С. Ниджлингаппа и больница Ханагал Шри Кумарешвар, Багалкот, \\ Карнатака, Индия \\ ${ }^{2}$ Медицинский колледж миссии Махатмы Ганди, Аурангабад, Махарастра, Индия \\ ${ }^{3}$ Медицинский колледж Махадеваппь Рампуре, Гулбарга, Карнатака, Индия \\ patilshw@gmail.com
}

Актуальность. Сахарный диабет представляет собой группу метаболических нарушений, при которых гипергликемия возникает либо из-за недостаточной секреции инсулина, либо из-за снижения чувствительности тканей к инсулину. Одним из наиболее распространенных осложнений диабета является нейропатия, и ее тяжесть будет зависеть от степени и продолжи- 
тельности гипергликемии. Хроническая гипергликемия при диабете приводит к поражению периферических нервов и замедляет психомоторные реакции у людей, у которых отсутствует надлежащий гликемический контроль. Снижение психомоторной реакции из-за недостаточности гликемического контроля влияет на время реакции у диабетиков.

Цель: оценить и сравнить время слуховой и зрительной реакций у больных диабетом в группах 1 и 2 , и провести корреляцию с уровнем гликозилированного гемоглобина (HbA1c) в обеих группах.

Методы. Исследование проводилось с участием 60 человек в возрасте от 40 до 50 лет после получения разрешения этического комитета нашего института. Группа состояла из 60 пациентов с хорошо контролируемым диабетом (HbA1c $<7 \%)$ в анамнезе от 1 до 10 лет, посещавших медицинский центр OPD в Басаешвар, Гулбарг. Пациенты с уровнем гемоглобина НbA1c 5-6\% были сгруппированы в группу 1, а пациенты с HbA1c 6-7\% - в группу 2. Время зрительной реакции на зеленый и красный свет, и время слуховой реакции на звук и щелчок измеряли с помощью прибора определения времени реакции $2 \times 4$, Anand agencies Pune. НbA1c определяли методом микроколонки.

Результаты. Время зрительной и слуховой реакций у больных диабетом группы 1 (HbAlc 5-6\%) было быстрее $\mathrm{P}<0,001$ по сравнению с больными группы 2 (НbA1c 6-7\%). Также была обнаружена статистически значимая положительная корреляция между уровнем HbAlc и временем зрительной и слуховой реакций.

Выводы. Плохой гликемический контроль замедляет психомоторные реакции и таким образом влияет на время зрительной и слуховой реакций.

Ключевые слова: диабет, гипергликемия, гликемический контроль, время реакции, HbA1c, диабетическая нейропатия. 